\title{
Non-Study Treatment Relationship
}

National Cancer Institute

\section{Source}

National Cancer Institute. Non-Study Treatment Relationship. NCI Thesaurus. Code C82564.

An indication or description of the correlation between a finding or event of interest and a treatment outside the specifications of a study. 